\title{
Store and release cover performance at Cadia Hill gold mine, Australia
}

\author{
T.K. Rohde Sinclair Knight Merz, Australia
}

D.J. Williams Golder Geomechanics Centre, The University of Queensland, Australia

J. Burton Newcrest Mining Ltd, Cadia Valley Operations, Australia

\begin{abstract}
The rehabilitation of waste rock dumps to minimise potential contamination is site specific; being a function, among other factors, of the rock types, the dumping and storage method employed, and the climatic setting. Three experimental store and release cover trials have been developed and constructed as part of a larger trial waste rock dump at Cadia Hill gold mine (Newcrest Mining) in Central New South Wales, Australia. The development of store and release cover systems for the temperate conditions typically experienced at Cadia (700 to 1,200 mm of rainfall annually) signals a significant departure from the climatic settings of other store and release cover system applications throughout Australia (typically semi-arid climates with less than half the annual rainfall of Cadia). The store and release cover system relies on the storage of rainfall during the wet season and its release during the dry season through evapotranspiration. It typically comprises a compacted fine-grained sealing layer (typically compacted clay) overlain by a significant thickness of loose "rocky soil mulch". Where there is a local paucity of clay and suitable rocky soil mulch, it may be possible to manufacture suitable cover materials from mixtures of benign tailings and benign waste rock crushed by haul truck trafficking. The paper describes trial store and release covers constructed at Cadia using such mixtures, the instrumentation of the trial covers and monitoring data collected over the past four years.
\end{abstract}

\section{Introduction}

This paper describes the design, construction and monitoring of three trial store and release cover systems for waste rock dumps at Cadia Hill gold mine in Central New South Wales, Australia. This included a laboratory investigation, numerical modelling, and instrumentation, including moisture and suction sensors, and lysimeters. The performance of the cover systems after four years is presented based on analysis of in situ sensor and lysimeter data.

\subsection{Site setting}

Cadia Hill open pit gold mine, located $25 \mathrm{~km}$ southwest of Orange in New South Wales, is the largest gold producer in the state and one of the largest open pit gold mines in Australia. Cadia Hill open pit had proven reserves of 200 million tonnes of ore, grading an average $0.73 \mathrm{~g} / \mathrm{t}$ gold and $0.17 \%$ copper. Cadia Hill open pit is scheduled for closure in 2012.

Cadia is located in a temperate climate with an average annual rainfall ranging from approximately 1,100 to $1,200 \mathrm{~mm}$ at the top of the catchment (above the open pit), to between 700 and $800 \mathrm{~mm}$ at the bottom of the catchment (below the pit; Williams et al., 2003b). Rainfall occurs predominately throughout the winter months, with low rainfall intensity events occurring throughout the rest of the year. The region experiences average maximum and minimum temperatures of $32^{\circ} \mathrm{C}$ and $6{ }^{\circ} \mathrm{C}$, respectively, and an average annual pan evaporation of $1,800 \mathrm{~mm}$, with average annual evapotranspiration taking up most of the annual rainfall. For the temperate climate described, it may not be possible to maintain high degrees of saturation within a waste rock cover to reduce oxygen diffusion through the cover; therefore, a suitable cover design would be one that is capable of minimising the net percolation to the underlying waste rock, in order to significantly reduce the magnitude of acid rock drainage. 


\subsection{Philosophy behind Cadia's store and release cover system}

Cover systems for potentially acid forming waste rock dumps in Australia have traditionally been mounded to shed rainfall run-off and hence minimise infiltration into the oxidising dump. A disadvantage of a rainfallshedding cover is that it may not have enough plant available water all year round to support long-term vegetation growth and will likely desiccate during dry periods, resulting in excessive erosion of the cover during the subsequent wet season. The store and release cover system developed for Cadia's waste rock dumps recognised the need to avoid rainfall run-off and desiccation, instead relying on storage within the cover of wet season rainfall and its release during the long subsequent dry season through evapotranspiration. Based on the Kidston mine site experience (Williams et al., 2003a), a store and release cover design could decrease the net percolation to the underlying waste rock to less than $1 \%$ of incident rainfall.

\section{Methodology}

The trials aimed to investigate modified store and release cover systems constructed using benign mine waste as a substitute for suitable natural soils, which were in short supply. For the modified store and release cover systems 5:1 (dry mass basis) mixtures of benign Trafficked waste rock (TWR) and tailings were used, either compacted dry or placed wet, to form a low hydraulic conductivity sealing layer at the base of the cover in place of the more usual compacted clay, and the same mixture placed loose was used as the overlying hummocked rocky soil mulch layer. The choice of a 5:1 TWR:tailings mixture was based on previous work at Cadia by Williams et al. (2003c). For the purposes of comparison, one of the three trial covers employed a compacted clay sealing layer.

\subsection{Conventional store and release cover system}

A schematic of a conventional store and release cover system is shown in Figure 1 (Williams et al., 2003a). The trafficked waste rock surface of the waste rock dump was sloped at a nominal $1^{\circ}$ gradient towards the final pit void to capture any breakthrough beneath the cover. Clayey weathered (oxide) waste rock was compacted to form a $0.5 \mathrm{~m}$ thick, near-saturated sealing layer, with a target saturated hydraulic conductivity of $1 \times 10^{-8} \mathrm{~m} / \mathrm{s}$.

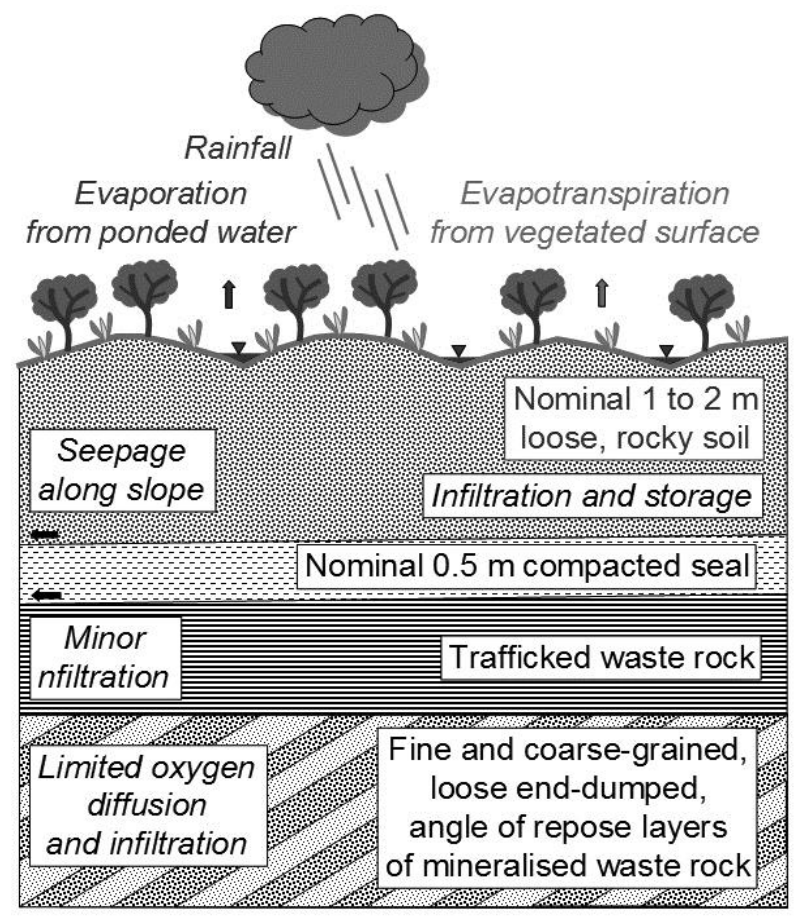

Figure 1 Schematic of store and release cover system (Williams et al., 2003a) 


\subsection{Modified store and release cover system trialled at Cadia}

Three trial store and release covers were constructed on top of a trial waste rock dump (Williams and Rohde, 2008) at Cadia, as follows:

1. "Natural cover" - Nominal $0.5 \mathrm{~m}$ thick compacted clay sealing layer, overlain by a nominal $1.5 \mathrm{~m}$ thick hummocked, loose-dumped rocky soil mulch layer comprising a 5:1 mixture of benign trafficked waste rock (nominal maximum size of $100 \mathrm{~mm}$ ) and dry, benign tailings excavated from the desiccated stored tailings.

2. "Dry cover" - Nominal $0.5 \mathrm{~m}$ thick compacted sealing layer, comprising a 5:1 mixture of benign trafficked waste rock (nominal maximum size of $100 \mathrm{~mm}$ ) and dry, benign tailings, overlain by a nominal $1.5 \mathrm{~m}$ thick hummocked, loose-dumped rocky soil mulch layer comprising a 5:1 mixture of benign trafficked waste rock and dry, benign tailings.

3. "Wet cover" - Nominal $0.5 \mathrm{~m}$ thick sealing layer, comprising a 5:1 mixture of benign trafficked waste rock and benign tailings slurry, overlain by a nominal $1.5 \mathrm{~m}$ thick hummocked, loose-dumped rocky soil mulch layer comprising a 5:1 mixture of benign trafficked waste rock and dry, benign tailings.

All three trial covers had a nominal $100 \mathrm{~mm}$ of topsoil spread over their hummocked top surface, with no seed mix (other than that naturally in the topsoil) added. The particle size distribution of the clay used to form the sealing layer in the natural cover comprised typically, $5 \%$ clay (passing $0.002 \mathrm{~mm}), 25 \%$ silt $(0.002$ to $0.06 \mathrm{~mm}), 50 \%$ sand $(0.06$ to $2 \mathrm{~mm})$, and $20 \%$ gravel $(2$ to $60 \mathrm{~mm})$. The compacted clay achieved an average in situ bulk density of $1.87 \mathrm{~g} / \mathrm{cm}^{3}$ and a saturated hydraulic conductivity of $3.3 \times 10^{-7} \mathrm{~m} / \mathrm{s}$.

The particle size distribution of the 5:1 Trafficked waste rock and tailings mixtures comprised typically 0\% clay, 5\% silt, 50\% sand, and 45\% gravel-sized particles. The compacted "dry" seal achieved an average in situ bulk density of $2.13 \mathrm{~g} / \mathrm{cm}^{3}$ and a saturated hydraulic conductivity of $1.8 \times 10^{-8} \mathrm{~m} / \mathrm{s}$. The "wet" seal achieved an in situ bulk density of $2.01 \mathrm{~g} / \mathrm{cm}^{3}$ and a saturated hydraulic conductivity of $1.8 \times 10^{-6} \mathrm{~m} / \mathrm{s}$.

The rocky soil mulch achieved an average in situ bulk density of $1.73 \mathrm{~g} / \mathrm{cm}^{3}$ and a saturated hydraulic conductivity of $2.4 \times 10^{-6} \mathrm{~m} / \mathrm{s}$. The loose dumping ensures a porosity of about 0.25 , which is available for the storage of rainfall infiltration. A $1.5 \mathrm{~m}$ thick mulch layer could therefore store up to $300 \mathrm{~mm}$ of infiltration (approximately one quarter the average annual rainfall at Cadia). Any excess water would serve to maintain the sealing layer near-saturated.

\subsection{Cadia trial cover materials and construction}

Clay for use in the natural cover sealing layer was sourced from a stockpile onsite, as was topsoil used to cover all three trial covers. Trafficked waste rock (TWR) was harvested from the trafficked surface of the access ramp to the trial waste rock dump adjacent to the trial covers (Figure 2 (a) and (b)). Dry tailings were excavated from the desiccated beach of the Northern Tailings Storage Facility, directly under a spigot outlet (Figure 2 (c)). Mixing of the TWR and dry tailings was facilitated by a dozer, using its bucket as a measure to approximate the required 5:1 ratio of TWR:tailings (Figure 2(d)).

Wet tailings were sourced directly from the mill and transported to trial cover site using a concrete mixer. They were poured into a bermed cell formed using TWR (Figure 3 (a) and (b)) to $500 \mathrm{~mm}$ depth. A tyremounted dozer was used to push TWR on a broad front into the wet tailings (Figure 3 (c)) until they no longer "bled" through the surface (Figure 3 (d)). 
(a)

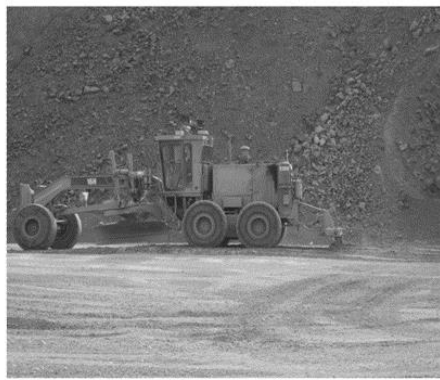

(c)

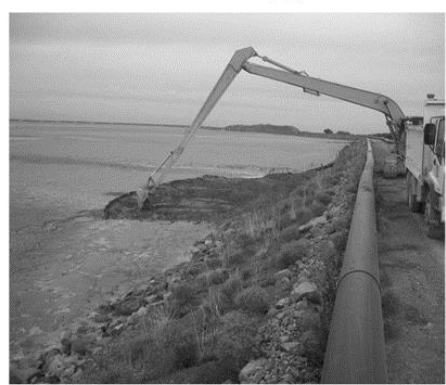

(b)

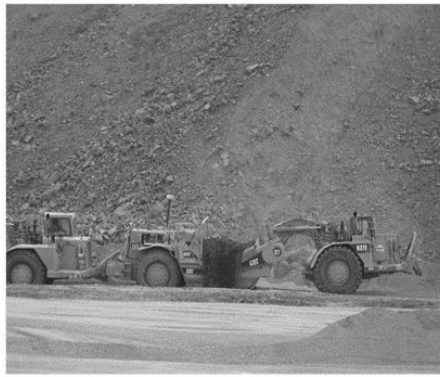

(d)

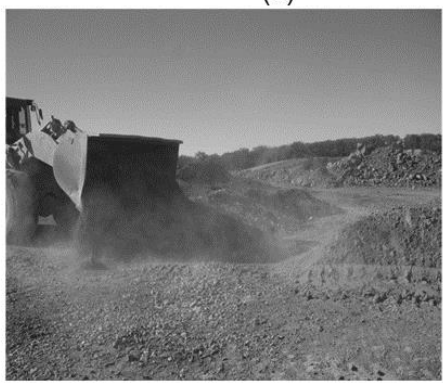

Figure 2 Harvesting and mixing 5:1 TWR and dry tailings for dry cover sealing layer and rocky soil mulch layer: (a) and (b) harvesting TWR, (c) harvesting dry tailings, and (d) mixing TWR and dry tailings

(a)

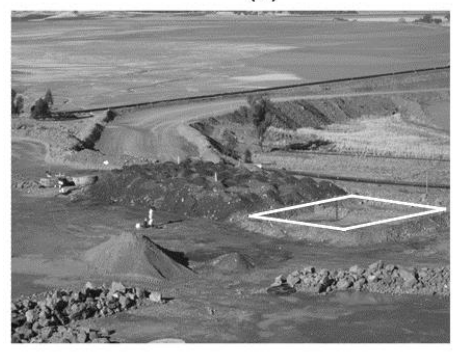

(c)

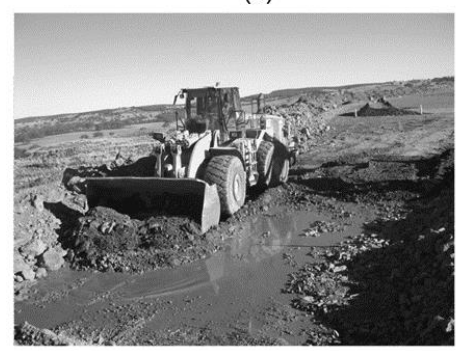

(b)

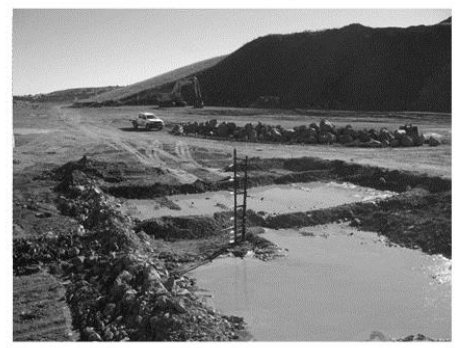

(d)

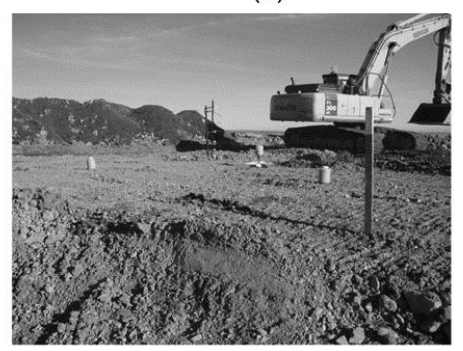

Figure 3 Construction of wet tailings and TWR sealing layer for wet cover: (a) bermed cell show in white, (b) wet tailings in bermed cell, (c) pushing in TWR, and (d) completed wet tailings and TWR sealing layer

\subsection{Cadia trial cover instrumentation}

The trial covers were instrumented with:

- Volumetric Water Content Sensors - Volumetric water content (VWC) is a percentage measure of water volume per total soil volume. It was measured at 12 depths within each trial cover using Campbell Scientific Time Domain Reflectometers sensors (CS610). 
- Matric Suction Sensors - Matric suction is a measure of the negative pore water pressure or capillary pressure that occurs as water is removed from the soil pore space. When combined with VWC, it is used to develop field soil water characteristic curves (SWCCs). The field soil water characteristic curves often differ to laboratory defined curves, due to the effects of natural cementation and the development of structure in the field, and can be used to calibrate unsaturated flow modelling. Matric suction was measured at 12 depths within each trial cover using Campbell Scientific Thermocouple Sensors (CS229).

- Lysimeters - A lysimeter is a buried open-topped water tank containing a rock filter at the base, with drainage to a rainfall tipping bucket at a down-slope low point. Lysimeters were used to physically measure the rate and quantity of percolation through the trial covers, and two were installed beneath each trial cover. Lysimeters require careful design to ensure that water does not wick towards, or away from, the device giving an erroneous infiltration result, and they also require careful design to ensure that they drain properly to the tipping buckets.

- A Weather Station - A local full weather station is required to capture rainfall and temperature data in the immediate vicinity of the trial covers. The Campbell Scientific weather station also enabled the calculation of evapotranspiration by the Penman-Monteith method.

Volumetric water content sensors and Matric suction sensors were embedded as pairs in the store and release cover systems. Pairing of the sensor types was intended to aid in the development of in situ soil water characteristic curves. Volumetric water content sensors do not require calibration and are accurate to within $\pm 5 \%$ (Campbell Scientific Inc., 2000). All store and release cover materials were within the acceptable electrical conductivity (EC) limits for the Campbell Scientific sensors. As the upper EC limit of $10 \mathrm{ds} / \mathrm{cm}$ was not exceeded for the host material the calibration functions of Topp et al. (1980) and Ledieu et al. (1986) apply to the current experimental design and on-going real time measurement system.

Campbell Scientific (CS229) Matric suction sensors were calibrated using a modified Tempe pressure cell with a 6 bar $(600 \mathrm{kPa})$ air-entry disc. Sensors were first pre-saturated in de-aired water under vacuum for 24 hrs. The saturated sensors were then placed in the modified Tempe pressure cell, embedding the sensors into saturated "rocky soil mulch" ensuring that good sensor/soil contact was achieved. The Tempe pressure cell was kept in a constant/temperature humidity room for the duration of the calibration process. A calibration function for these sensors has also been described by Flint et al. (2002) and Campbell (2006).

Where sensors were required to be placed after the compaction of the sealing layers for the natural and dry covers, an access trench was excavated through the full thickness of the sealing layer and sensors were pushed into the access trench wall. The trench was then backfilled to the approximate density of the surrounding material. Following the construction of the compacted clay and dry 5:1 TWR/tailings sealing layers, and prior to construction of the wet sealing layer, paired moisture and suction sensors were installed on vertical guyed sensor towers (Figure 4 (a)) and the rocky soil mulch was placed around them.

Four of each sensor type were installed at even intervals in the base sealing layer, with the remaining eight installed in the rocky soil mulch layer. Within the rocky soil mulch layer, sensors were concentrated towards the boundary with the seal and towards the surface, since these were deemed to be the areas of most interest. The hummocked surface surrounding each vertical sensor tower was constructed first, ensuring that good sensor contact was made with the surrounding material and that the guyed tower remained vertical sensors were placed perpendicular to the ground surface, avoiding a hydraulic gradient along the sensor length (Figure 4 (b) and (c)). The completed hummocked surface of the rocky soil mulch layer was then topsoiled (Figure $4(\mathrm{~d})$ ).

Buried either side of the guyed sensor tower beneath each trial cover, a pair of lysimeters was installed in $2.45 \mathrm{~m}$ deep holes in the waste rock dump surface, excavated using a track mounted excavator (Figure 5 (a)). The waste rock was placed on the surface in a series of separate piles so that it could be backfilled into the lysimeters and surrounding void in approximately the same sequence as it was removed (Figure 5 (a, b, c and d)). A uniform, coarse mine aggregate termed "crusher dust" (with a maximum particle size of approximately $10 \mathrm{~mm}$ ) was placed in the base of each void created by the excavator to raise the base of the void to an average $2.4 \mathrm{~m}$ depth, providing an even base for the lysimeter to sit on and a $0.5 \%$ gradient to the proposed drainage point. A small void was made in the crusher dust at the drainage point to accommodate an 
S-bend fitting and drainage for the lysimeters. Once bedded, the lysimeters ( $2.4 \mathrm{~m}$ diameter by $2.3 \mathrm{~m}$ height) sat flush with the trafficked surface of the trial waste rock dump.

Lysimeter design for non-atmospheric conditions creates an elevated water boundary condition at the base of the lysimeter and therefore the lysimeter's internal hydraulic gradient is different to the surrounding in situ environment (Bews et al., 1997; O'Kane and Barbour, 2003). To correct this discrepancy created by non-atmospheric conditions, the lysimeter wall height needs to exceed the height of capillary rise above the water table. This condition will be satisfied when the applied flux is equal to the hydraulic conductivity of the backfilled material. The lysimeter wall height was designed using the principles described by Bews et al. (1997) and O'Kane and Barbour (2003).

(a)

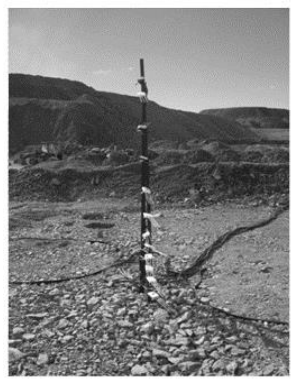

(c)

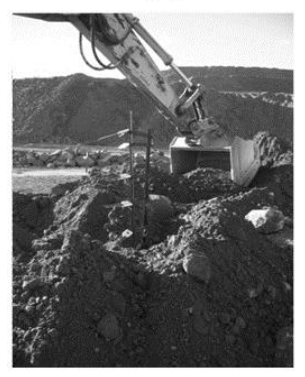

(b)

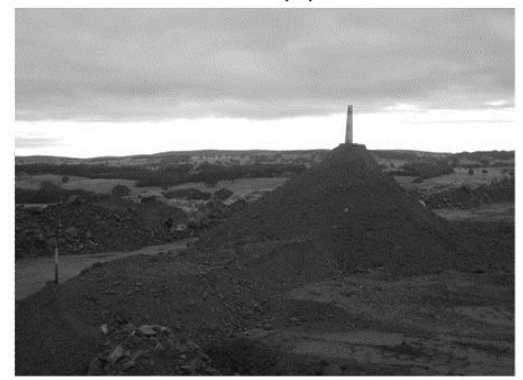

(d)

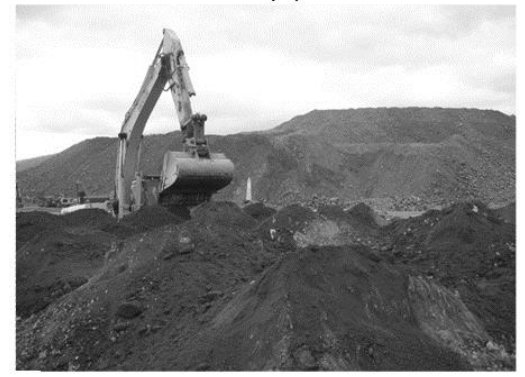

Figure 4 Cover sensor placement: (a) vertical guyed sensor tower, (b) full-height rocky soil mulch around tower, (c) placing rocky soil mulch around tower, and (d) topsoiling hummocked rocky soil mulch

(a)

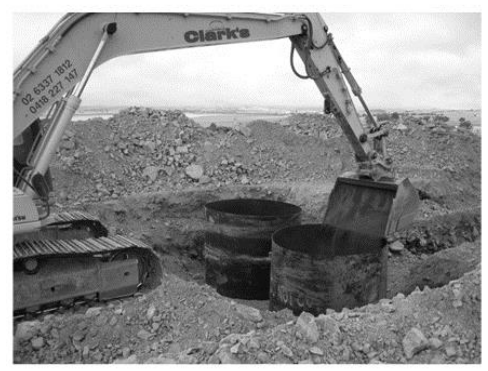

(d)

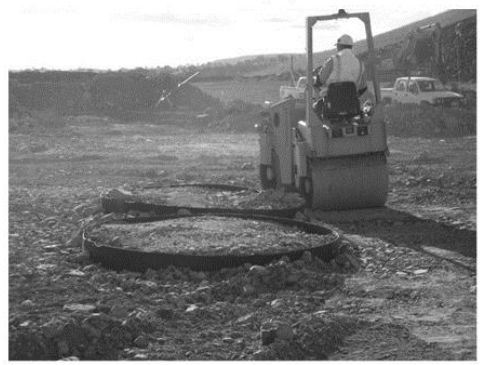

(b)

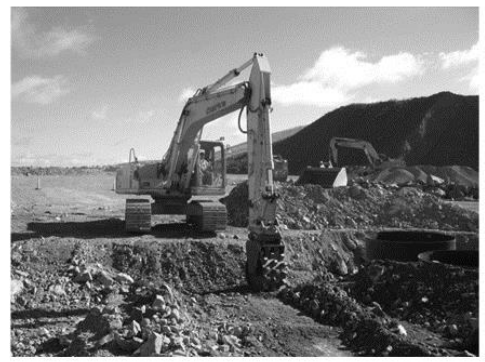

(e)

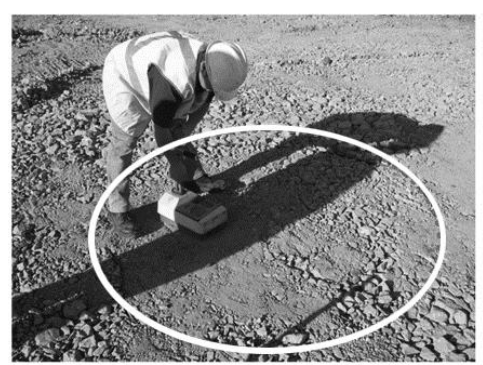

(c)

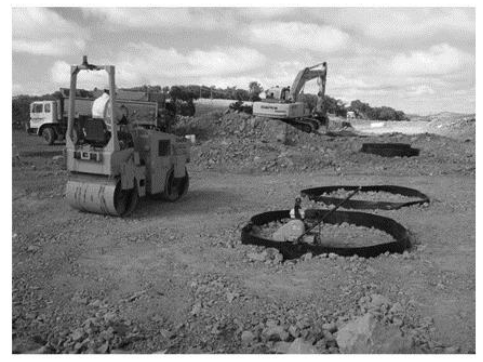

(f)

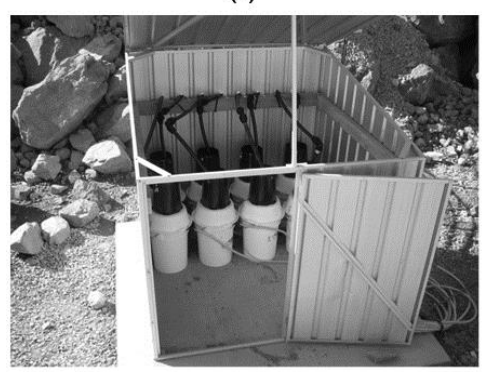

Figure 5 Surface lysimeter construction sequence 


\section{$3 \quad$ Monitoring results}

\subsection{Net percolation through trial covers}

The annual rainfalls recorded at the trial covers has been $606 \mathrm{~mm}, 927 \mathrm{~mm}, 1,553 \mathrm{~mm}$, and 1,609 $\mathrm{mm}$, for 2006/2007, 2007/2008, 2008/2009 and 2009/2010, respectively. The first two years of the monitoring period had significantly less than the average annual rainfall for the site, while the final two years of monitoring have been above the average annual rainfall. Ponding of water in the hollows of the mounded covers has been observed during the wet season, and no significant cracking of the surface has been observed during the dry season.

Figure 6 shows the lysimeter flow rates (as a percentage of cumulative rainfall) for the two lysimeters under each of the three trial store and release cover systems. Net percolation through all three trial store and release cover systems has trended towards $1 \%$ of incident rainfall over the 4 years of monitoring. The natural cover, with a compacted clay sealing layer that was placed well dry of optimum, did not begin to report any net percolation until January 2007. One lysimeter has reported up to $1 \%$ of cumulative rainfall, while the other has continued to report negligible net percolation.

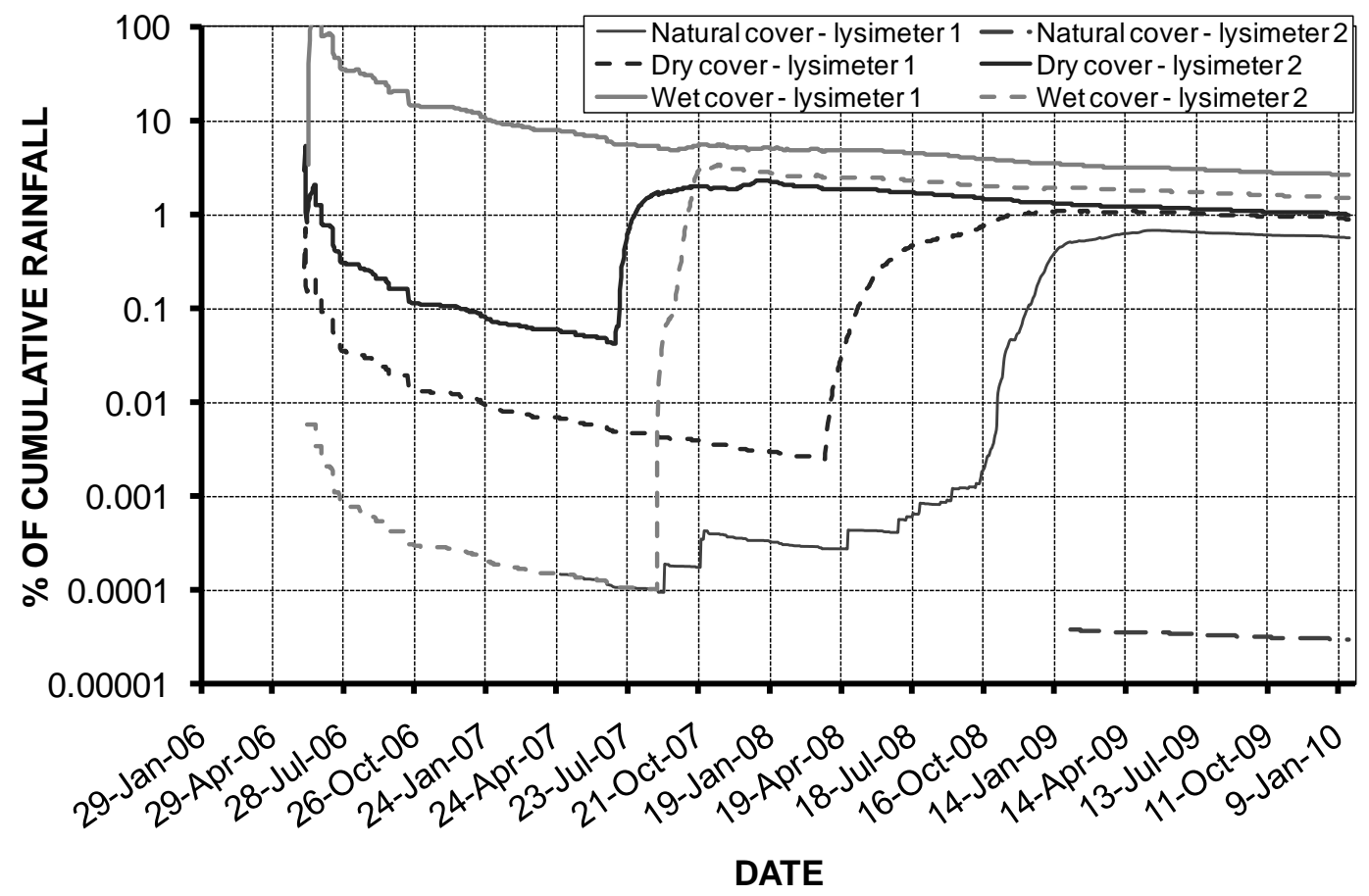

Figure 6 Percentage of cumulative rainfall: store and release cover system lysimeters

The dry cover with a compacted sealing layer comprising 5:1 TWR and dry tailings initially reported a receding net percolation, but net percolation increased from mid 2007, before trending down towards $1 \%$ of cumulative rainfall. The initial net percolation in excess of $1 \%$ of cumulative rainfall is likely due to the addition of water to moisture-condition the 5:1 TWR/tailings mixture used for the compacted sealing layer.

The wet cover with a sealing layer comprising 5:1 TWR and wet tailings introduced considerable excess water into the sealing layer, which has percolated into the underlying waste rock at a diminishing rate, with the net percolation trending towards $1 \%$ of cumulative rainfall after 4 years.

\subsection{Moisture states within trial covers}

Figure 7 shows the volumetric water content plots with time for the 12 volumetric water content sensors spanning the full $2.5 \mathrm{~m}$ thickness of the trial natural cover, constructed with a compacted clay sealing layer. There is very little redistribution with time of volumetric water content and hence moisture below about $1.9 \mathrm{~m}$ depth within the cover; that is, below the upper part of the sealing layer. There has been some 
preferential flow through the cover as indicated by individual spikes above the saturated porosity (averaging 0.3 and 0.22 for the rocky soil mulch and compacted clay sealing layers, respectively).

Figure 8 shows the volumetric water content plots with time for the trial dry cover, constructed with a compacted 5:1 TWR and dry tailings sealing layer. While the volumetric water content data are highly variable, they illustrate a number of key results. Volumetric water remained concentrated in the lower $1 \mathrm{~m}$ thickness of the rocky soil mulch layer, which was placed during rainfall and retained a higher porosity and volumetric water content. The compacted sealing layer is seen to wet-up over the first 60 days of monitoring, followed by drying to near residual water content over time, with seasonal variations. Hence, the sealing layer appears to be effective in holding-up the water in the rocky soil mulch layer.

Figure 9 shows the volumetric water content plots with time for the trial wet cover, constructed with a 5:1 TWR and wet tailings sealing layer. The disparity between the volumetric water contents of the sealing layer and the rocky soil mulch layer is pronounced. The use of wet tailings has maintained the sealing layer nearsaturated, with limited net percolation to the underlying waste rock. The rocky soil mulch layer has undergone seasonal wetting and drying cycles as expected, but holds much less water than the sealing layer and is apparently not contributing to net percolation.

Seasonal variations in volumetric water content are clearly evident for all trial covers, with all three trial covers showing a downward trend over time.

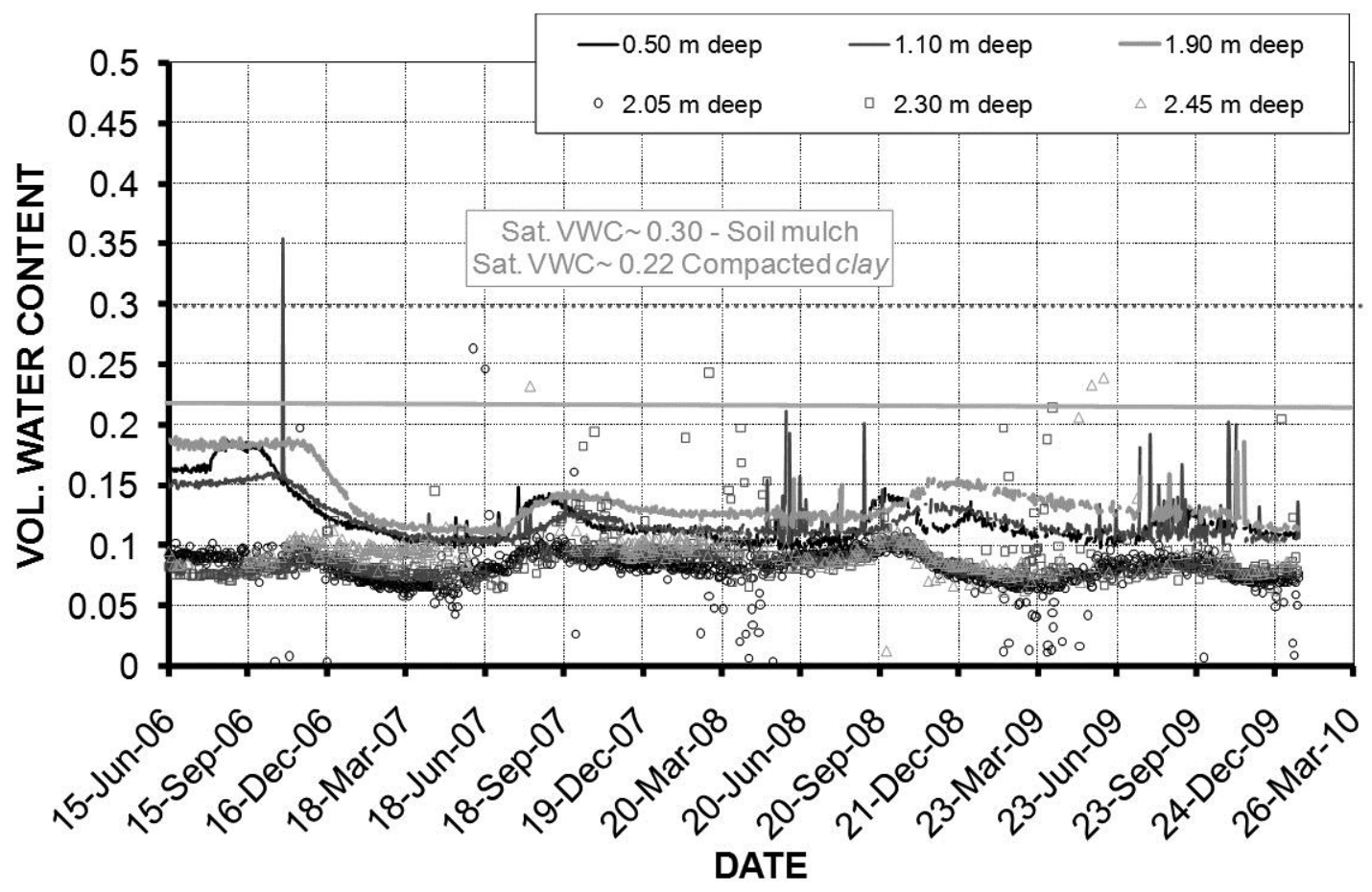

Figure 7 Natural cover moisture state over time 


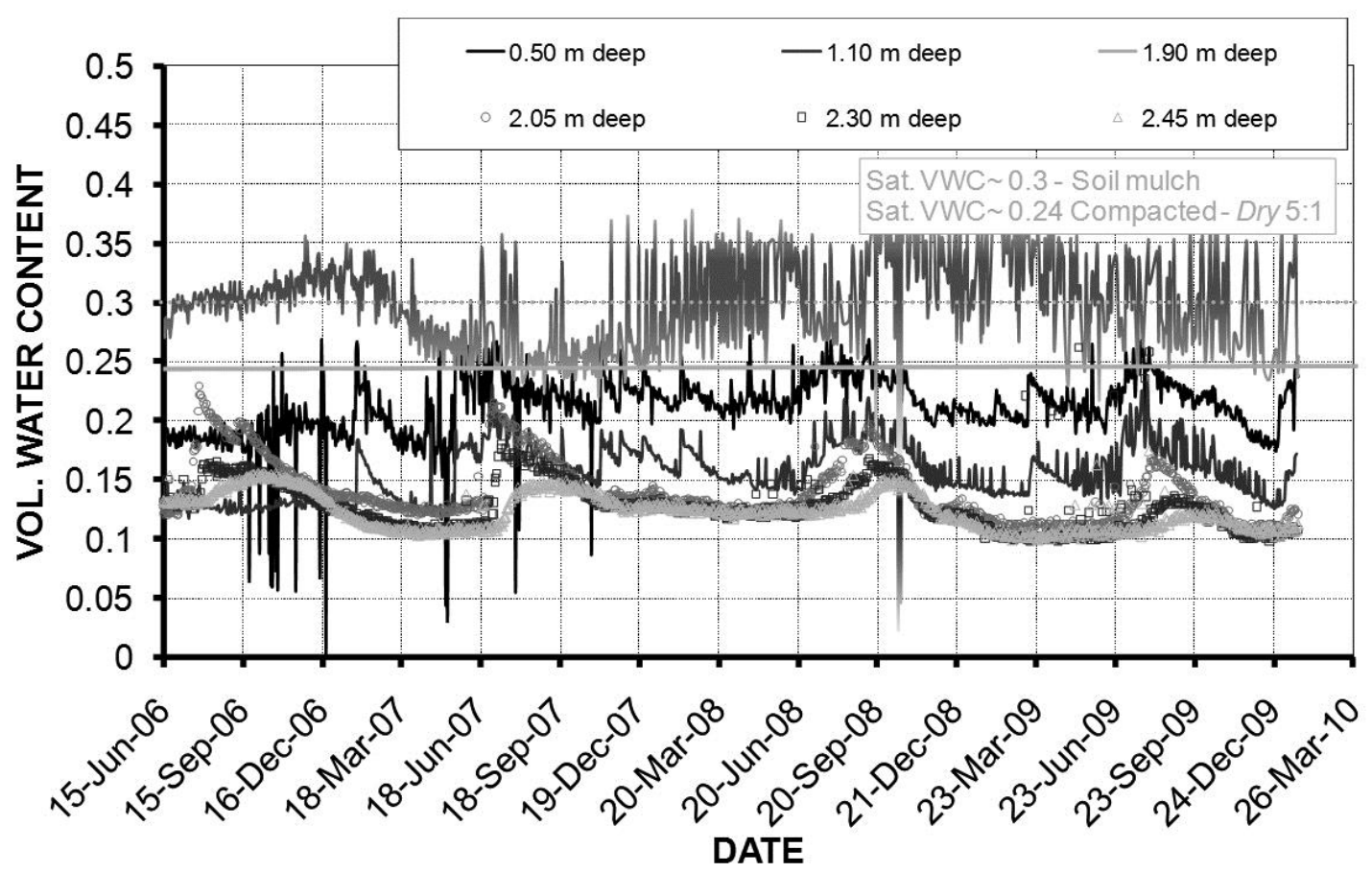

Figure 8 Dry cover moisture state over time

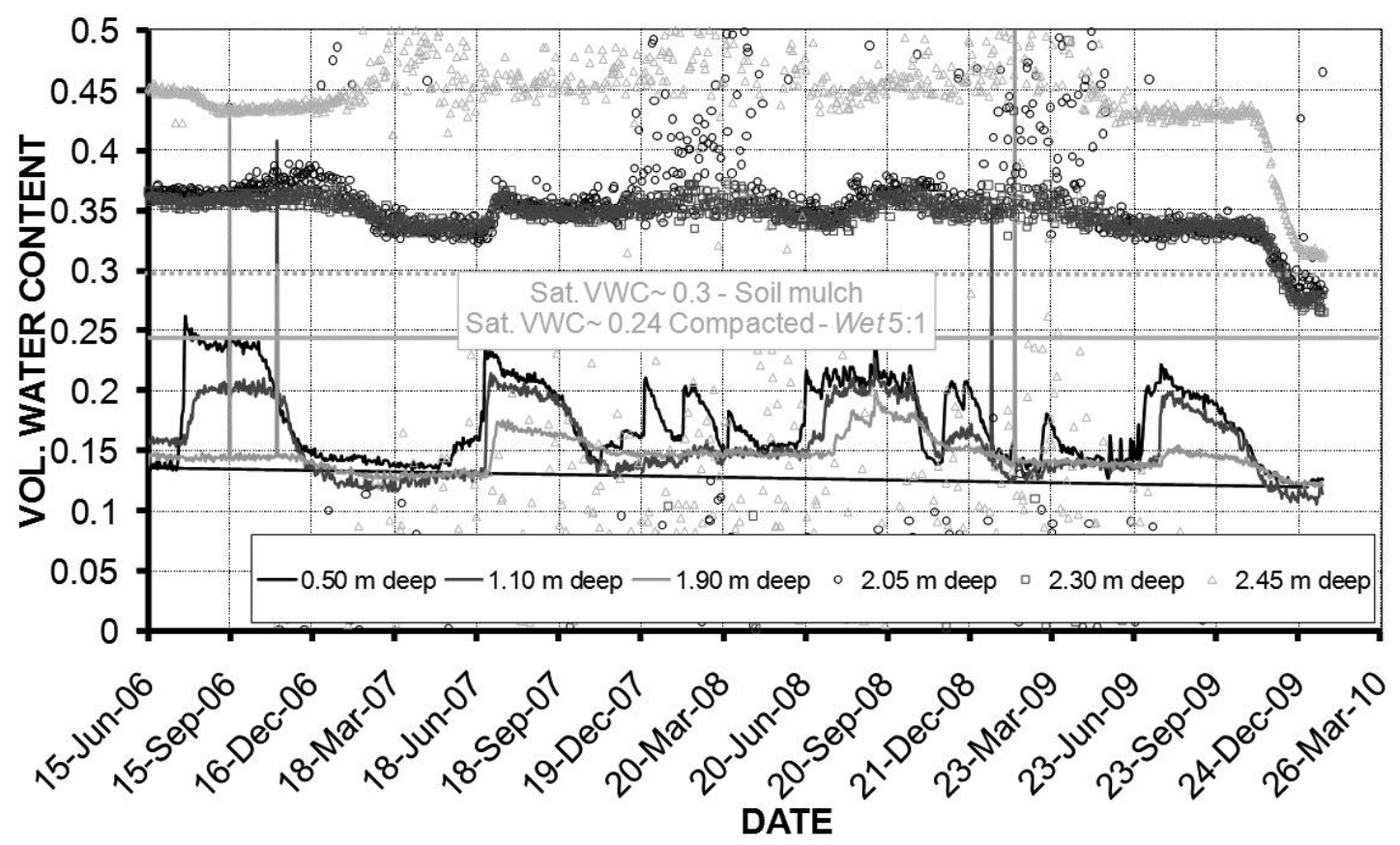

Figure 9 Wet cover moisture state over time

\subsection{Importance of vegetation}

The appropriate choice and sustainability of vegetative cover on a store and release cover system is essential to its effectiveness in limiting rainfall infiltration. The store and release cover systems reported within this study were not seeded, but became vegetated over time with volunteer grasses and weeds. The long-term performance of the store and release cover system trials at Cadia Hill gold mine will likely improve with the addition of Australian native species that would increase the evapotranspiration rate, and reduce still further the observed percolation rates through the covers. 


\section{Conclusions}

Cadia Hill gold mine has demonstrated through field trials that store and release cover systems have the potential to address the possible future release of acid rock drainage to the receiving environment. While the best-performing trial store and release cover involved a compacted clay sealing layer, all three trial covers performed well in the longer-term. The natural cover with a compacted clay sealing layer was constructed well dry of optimum, which accounted for its negligible initial net percolation. After 4 years its net percolation had risen, but remained below $1 \%$ of cumulative rainfall. The dry cover with a compacted 5:1 TWR and dry tailings sealing layer performed next best, with a net percolation of about $1 \%$ of cumulative rainfall after 4 years. The wet cover with a 5:1 TWR and wet tailings sealing layer performed least well, with high initial net percolation due to the use of wet tailings, but after 4 years its net percolation is trending towards $1 \%$ of cumulative rainfall.

A rocky soil mulch layer comprising loose 5:1 TWR and dry tailings appears a suitable substitute for natural materials, with any variation in performance due to its moisture content at the time of placement.

It is clear that the early performance of store and release covers is very much dependent on the moisture state of the materials used at the time of construction, and that it takes several years for their likely long-term behaviour to become apparent. There is a need, therefore, to maintain monitoring for the order of 10 years to assess the cover system at equilibrium under a range of climatic conditions.

\section{Acknowledgements}

The authors gratefully acknowledge the management of Cadia Holdings Pty Limited and ARC Linkage for funding the research project on which this paper is based.

\section{References}

Bews, B., Wilson, G. and O'Kane, M. (1997) The design of lysimeters for low flux cover systems over acid generating waste, Proceedings of Canadian Geotechnical Golden Jubilee Conference, Canadian Geotechnical Society, Alliston, pp. 26-33.

Campbell Scientific Inc. (2000) Instruction Manual for TDR100, Revision 4/02.

Campbell, G. (2006) Calibration of Heat-Dissipation Sensors (CS229): Technical Note from Geochemistry/Soil-Physics Laboratory.

Flint, A., Campbell, G., Ellet, P. and Calissendorff, C. (2002) Calibration and Temperature Correction of Heat Dissipation Matric Potential Sensors, Soil Science Society of America Journal, Vol. 66, pp. 1439-1445.

Ledieu, J., De Ridder, P., De Clerk, P. and Dautrebande, S. (1986) A method of measuring soil moisture by timedomain reflectometry, Journal of Hydrology, Vol. 88, pp. 319-328.

O'Kane, M. and Barbour, L. (2003) Predicting Field Performance of Lysimeters Used to Evaluate Cover Systems for Mine Waste, Proceedings of Sixth International Conference on Acid Rock Drainage, 14-17 July 2003, Cairns, Australia, Australian Centre for Mining Environmental Research, Brisbane, pp. 327-339.

Topp, G., Davis, J. and Annan, A. (1980) Electromagnetic determination of soil water content: measurement in coaxial transmission lines, Water Resources Research, Vol. 16, pp. 574-582.

Williams, D., Currey, N., Ritchie, P. and Wilson, G. (2003a) Kidston Waste Rock Dump Design and 'Store and Release' Cover Performance Seven Years On, Proceedings of Sixth International Conference on Acid Rock Drainage, 14-17 July 2003, Cairns, Australia. Australian Centre for Mining Environmental Research, Brisbane, pp. 419-426.

Williams, D., Jeffery, J., Gilbert, L., Wilson, G., Panidis, C. and Perry, B. (2003b) A review of the Acid Rock Drainage Potential and Hydrological Implications of Selectively-Placed Waste Rock at a Gold Mine in NSW, Australia, Proceedings of Sixth International Conference on Acid Rock Drainage, 14-17 July 2003, Cairns, Australia, Australian Centre for Mining Environmental Research, Brisbane, pp. 949-954.

Williams, D., Wilson, G. and Panidis, C. (2003c) A review of the Acid Rock Drainage Potential and Hydrological Implications of Selectively-Placed Waste Rock at a Gold Mine in NSW, Australia, Proceedings of Sixth International Conference on Acid Rock Drainage, 14-17 July 2003, Cairns, Australia, Australian Centre for Mining Environmental Research, Brisbane, pp. 427-435.

Williams, D.J. and Rohde, T.K. (2008) Waste rock dump rainfall infiltration and base seepage at Cadia, Proceedings of Sixth Australian Workshop on Acid and Metalliferous Drainage, Burnie, Australia, 15-18 April 2008, Burnie, Australia, Australian Centre for Mining Environmental Research, Brisbane, pp. 151-162. 